УДК 113:159.955

doi.org/10.33989/2075-1443.2019.41.172999

orcid.org/ 0000-0003-0844-4004

\title{
Ірина Цебрій
}

ЦЕБРІЙ Ірина Василівна - доктор педагогічних наук, професор кафедри всесвітньої історії та методики викладання історії Полтавського національного педагогічного університету імені В.Г. Короленка. Сфера наукових інтересів - європейська філософія пізнього Середньовіччя та Північного Відродження.

\section{УЯВЛЕННЯ ПРО ГАРМОНЮЮ ЛЮДСЬКОГО ЖИТТЯ І КОСМОЛОГІЧНІ ВИМІРИ В ТВОРЧОСТІ АНТОНІО ФЕРРАБОСКО}

У статті йдеться про гармонію людського життя $і$ космологічні виміри в творчості Антоніо Феррабоско, щяо були англійським мистеиьким феноменом рубежу XVI - XVIII століть. Аналізуючи праиі провідних дослідників англійського театру та оригінальні тексти музичних вистав Антоніо Феррабоско, автор розкриває символізм англійського театру на перехідному етапі від пізнього Середньовіччя до раннього Північного Відродження. Водночас багатогранність иього символізму заперечує думку дослідників XIX століття, щзо в театрі «Глобус» звучала лише музика та поетичне слово, а театральна дія була повністю відсутньою. Доводяться положення, що гармонія музики мала призначення стати організаційним началом всього спектаклю, містити його пластичні образи, відобразити космологічні виміри англійців на рубежі епох.

Ключові слова: космологічні виміри, гармонія, символізм, театральна дія, музика, «театр масок», Північне Відродження.

Постановка проблеми. Уявлення про гармонійне людське співіснування, про світло й сутінки в земному житті, роль землі та моря, значення рослин і тварин у навколишньому світі знайшли своє відображення в англійському театрі рубежу XVI - XVIII століть. Космологія як учення про Всесвіт у цілому та про місце людства у ньому мала особливі виміри в творчості Антоніо Феррабоско - англійського драматурга і композитра, трупа якого до 1602 року ділила сцену легендарного театру «Глобус» разом із В. Шекспіром.

(C) І. В. Цебрій, 2018 
Проблемі космологічних вимірів в театральній творчості Антоніо Феррабоско присвячені праці Д. Саприкіної та І. Цебрій (Саприкіна, 2019; Цебрій, 2019). Аналіз уявлень про гармонію людського життя даний у наукових розвідках Г. Бояджиєва й Г. Всеволодського (Дживелегов, 1984; Всеволодский, 1913). Проте на сьогоднішній день практично немає таких праць, де б була розкрита проблема цілісних уявлень про гармонію людського життя і космологічні виміри в творчості Антоніо Феррабоско як англійський феномен рубежу XVI - XVIII століть. Тому автор статті ставить мету відобразити цілісну картину людського співіснування, зміни світла й сутінок проекції землі та моря, значення рослин і тварин у сценічному дійстві драматургів «Глобусу».

Виклад основного матеріалу. Отже, в Англії здавна існував найоригінальніший музично-театральний жанр, що мав спеціальну назву «Маски». Це були придворні спектаклі, котрі з'явилися в Лондоні на початку XVI століття. Алегоричні та міфологічні за змістом, вони були поєднанням різних театральних жанрів - ліричного, драматичного, комічного, перепліталися із сатиричними вставками на повсякденні теми, переодяганнями, піснями, танцями, інструментальною музикою.

Структура «Масок» представляла дивертисмент із різних номерів: драматичних діалогів, комічних інтермедій, ліричних епізодів, комедійних епізодів на сучасні теми. Та все-таки пізнішого часу мали й наскрізний розвиток єдиного сюжету з усіма необхідними атрибутами. «Маски» обов〉язково оформлювалися пишними декораціями.

Створенням музики та тексту «Масок» захоплювалися багато талановитих драматургів і музикантів. Виконавцями дійства були як аматори, так і професіонали. Маски ставилися у королівських палацах, або в палацах аристократів, які дбали про утримання акторів, виготовлення костюмів і декорацій, створення майданчиків або спеціальних кімнат у зимову пору.

Своєї вершини в розвитку жанр «Масок» досяг у другій половині XVI - початку XVII ст. Тексти для «Масок» цього часу писали відомі поети та драматурги - Ф. Сідні, Ф. Бомот, Дж. Мільтон. Вперше в «Масці» Кампіона зустрічаються музичні діалоги, а речетативний стиль свого часу був уведений С. Ланьїром у масці «Закохані в людській подобі» (1597р.).

Окрему театральну сторінку Англії склали «Маски» братів Лоус і А. Феррабоско. Їхні «Маски» мали наскрізний розвиток сюжету, хори, діалоги, монологи, арії, оркестровий супровід, балетний дивертисмент. Англійські музикознавці й театрознавці XIX ст. вбачали у творах цих авторів різновидність національної англійської опери. 
Брати Лоус і А. Феррабоско брали для своїх «Масок» винятково сатиричні сюжети. А. Феррабоско не лише писав музику до «Масок», а й створював лібрето у віршованій формі. Англійські дослідники театру «Масок» (Е. Дент, І. Маніфольд) стверджували, що трупа А. Феррабоско певний час співпрацювала із трупою В. Шекспіра в театрі «Глобус».

Театрознавці, які вивчали творчість братів Лоус і А. Феррабоско, спираючись на щоденники Б. Джонсона, аналізували суть дружніх дискусій між В. Шекспіром і А. Феррабоско щодо ролі музики та слова в театральному дійстві (Цебрій, 2019, с. 19).

Із часів В. Гете була розповсюджена думка, що в «Глобусі» мало місце лише одне слухове враження за відсутності сценічної дії. А таємничий, зруйнований полум'ям «Глобус» був просто театром, де збиралися любителі високого поетичного слова (Всеволодский, 1913, с. 205).

Англійські дослідники XX ст. (Д. Мерсер, Д. Осборн) заперечували цю думку. «Глобус» був майже досконалою театральною будовою. I навіть Шекспір, а не лише Феррабоско, беззаперечно вірив у словесне чародійство. У В. Шекспіра під впливом А. Феррабоско склалося особливе відношення до музики. До неї він звертається частіше, ніж до живопису, скульптури. Міркуючи про музику, Шекспір визначає гармонію дійства. У його виставах є місце для гармонії цілісного людського існування, гармонії закоханих, навіть для гармонії, якої досягає змучена, але мужня душа в кінці шляху - тоді його герої чують музику небесних сфер. В ідеалі гармонія музики призначена була стати організаційним началом всього спектаклю, містити його пластичні образи (Саприкіна, 2019, с. 51).

Пластичний світ А. Феррабоско на сцені «Глобуса» за думкою дослідників, двореальний. Він існував на сцені та в уяві одночасно, але не завжди паралельно. Для розуміння того, як виник англійський театр «Маски», що узгоджено поєднував цілий світ, необхідно розуміти його природу:

світло й сутінки;

роль землі та моря;

значення рослин і тварин в англійському театрі.

Дві головні стихії - світло й сутінки, що в А. Феррабоско виступають тотожними категоріям істини та брехні, прекрасного й потворного, склали теоретичні засади театру. У багатьох віршах він оспівує світло: сяйво місяця, сонця й зірок; коливання вогню, факела та свічки; блискучі німби святих і палаючу вночі красу закоханих. В А. Феррабоско є фрагменти, котрі відображають сутінки, темряву: ніч, затемнення, сутінки лісу, темне черево гнилих боліт, де народжується нечисть, бурі, 
що знищують своєю чорнотою світло неба й усю землю занурюють у темряву (Дживелегов, 1984, с. 79).

Межею між добром і злом виступають темні печери, де ховаються привиди та чарівники. Якщо у віршах свічку запалюють вночі, то на сцені «Глобусу» - вдень, бо саме в цей час починалися вистави.

Проте, за всіма свідченнями очевидців, на сцені «Глобусу» навіть удень було місце, де концентрувалися сутінки - ніша в заглибленні сцени, темна посеред ясного дня, подібна враженню від темного вікна, якщо ми з вулиці дивимося на нього вдень. Із цієї ніші для презентації виходили актори в масках, а потім там вони таємниче й зникали. Звідси з'являлися привиди.

Земля була зображена в дійстві як образ батьківщини людства: тут була й земля воїнів — поле безкінечних битв, була земля закоханих ніжні зелені сади. Земля в театрі складалася $з$ дерев〉яних дощок сцени, що звужувалися до переднього краю. Сцена також символізувала місце існування людини: палаци, собори та міста (Дживелегов, 1984, с. 81).

Небо ж у дійстві завжди було мінливим, виступало символом непевності людського існування. Його сяйво змінювалося напівсутінками, а потім темрявою ночі, що закінчувалася сірим і безрадісним ранком. Через хмари проникало сонячне проміння й дарувало невеликі земні радощі героям.

Над невеликою частиною сцени був натягнутий тент під навісом i3 колонами: голубий для комедійного дійства й чорний iз золотими зірками для серйозних подій. Це було також небо - умовне, театральне. Але було й справжнє небо над театром, який не мав даху. Якщо починався дощ, то виставу відміняли. У випадку чудової погоди піднімався настрій як у глядачів, так і у виконавців.

Mope, як світло, небо та земля також були одним із головних поетичних образів, А. Феррабоско, багатоликим його символом. Під час «Масок» глядачі іноді відчували, як по ньому летять човни й невідомі риби мешкають у цих водах. Бурі на сцені «Глобусу» займали особливе місце у сценічному дійстві: люди купчилися, намагалися за щось ухопитися, всі вони були одягнені в щільні мокрі плащі. Якщо все завершувалося добре, актори посміхалися, скидали темні плащі. Тоді глядачі спостерігали яскраві сукні, що були під плащами.

Та в очах англійської публіки - морської нації - міг виникнути й інший образ. Клиноподібна сцена «Глобусу» втілювала була втіленням життя - корабель у вічному океані на одинокій планеті, що пливке серед ворожих і добрих зірок. I ці зірки відбивалися у водах Темзи, коли глядачі на човнах пливли додому після спектаклю, обмінюючись свіжими враженнями. 
У сюжетах А. Феррабоско дерева, квіти, трави, що оточують людину та прикрашають іiі черевики й деталі одягу, наче перебралися сюди $з$ пергаментів ботанічних трактатів, готичних картин і шпалер. Прте, не лише у віршах і музиці пахли квіти, плили по воді лілеї, височіли дерева. Глядачі відчували їхню присутність зовсім поряд, за стінами театру. На сцені квітів і рослин було достатньо. Із речитативів дійових осіб відчутно, що букети квітів персонажі тримали в руках, дарували одне одному, прикрашали подруг гірляндами та вінками. I це відповідало звичаям і моді тих часів взагалі. Квіти були найдоступнішою, найголовнішою прикрасою для всіх станів англійського суспільства. Навіть злидар у свято прикрашав шляпу квіткою або гілочкою зелені. Квітами і травами застилали підлогу для балу чи весілля. Все це дійство відповідало мові квітів того часу. I хоча квіти на сцені були штучними, їх все ж можна було роздивитися.

Людину театрального світу навкруги оточують тварини. Пір>я у злеті, граціозний рух слизьких і блискучих риб, переливи бавовни все це мало справжню пластику й у віршах і в музиці (Адиссон, 2005, c. 23).

Утіленням єдності людини з тваринним світом, образом античної фантастичної природи на сцені «Глобусу» був своєрідний «кентавр». У випадку щасливого кінця «Маски» для виконання фінального фрагменту з>являвся «коник», власне кінська голова та хвіст на палиці. Людина сідала верхи на палицю, а довга спідниця-попона накривала ноги «кентавра», який у танці відображав кінний біг і стрибки. Така карнавальна істота прийшла до театру А. Феррабоско з народного свята, 3 казкового середньовічного «бестіарію».

Так вимальовувався театр пізньої англійської «Маски» - цілий світ зі своєю незвичною театральною природою, де просліджувалися свої закономірності в засобах виразності та театрального відображення дійства. Та в центрі театру «Маски» стояла людина. Вона також була особливою - театральною. Звертаючись до неї, Феррабоско міг би повторити слова Піко делла Мірандоли з його «Промови про достоїнство людини»: «Я ставлю тебе у центрі світу, щоб звідти тобі зручніше було охопити все, що є у світі. Я не зробив тебе ні небесним, ні земним, ні смертним, ні безсмертним, щоб ти сам, вільний і славний майстер, сформував себе в образі, який ти для себе обереш» (Всеволодский, 1913, с. 118).

Найвідоміша «маска» А. Феррабоско «Про дівчинку-мулатку, яка розкидала коштовності», за ствердженнями англійських дослідників, мала величезний успіх на сцені «Глобусу», повністю втілила ідеї умовного театрального світу рубежу XVI - XVII століть. 
Серйозні зміни у ході розвитку англійського театрального мистецтва були викликані революційними подіями. Пуританізм протиставив світському театру та драматизованим католицьким месам своє релігійне бачення форм - псалми, антеми, що пізніше були використані в творчості Г. Перселла. Суворо аскетичне релігійне вчення пуритан було спрямоване проти світського театру. Окремі історики справедливо вбачають у діях пуритан, їхньому аскетичному світогляді одну 3 найсерйозніших причин загибелі національного світського та музично-драматичного театрів, бо в минулому театральне мистецтво в англійців не лише не поступалося оригінальністю, інтенсивністю розвитку іншим європейським країнам (Німеччині, Франції), а й випереджало їх (Всеволодский, 1913, с. 121).

Англійський публіцист XVII ст. Р. Адіссон в одній із журнальних статей гірко констатував загальний занепад національного театру: «Сьогодні наша уява про театр настільки нечітка, що ми навіть не знаємо, що ми в ньому любимо; ми захоплюємося взагалі всім неанглійським, аби це був іноземний твір, італійський, французький чи німецький. Це нам без різниці, коротко кажучи, наш англійський театр, славний «театр масок» метра Антоніо Феррабоско, знищений повністю і нічого нового не посіяно на його місці» (Адиссон, 2005, с. 24).

Зазначимо, що театральні вистави системно відновилися лише за часів реставрації монархії Стюартів у 1660 році. Проте, це вже був не той театр.

Висновки. Таким чином, уявлення про гармонію людського життя і космологічні виміри в творчості Антоніо Феррабоско були дійсно англійським мистецьким феноменом рубежу XVI - XVIII століть. Кожна деталь п'єси чи театрального оздоблення мала свій символічний зміст. Клиноподібна сцена «Глобусу» відображала одинокий корабель, що мандрує серед непередбачених стихій планети (Всесвіту). Театральна зміна світла й сутінок підкреслювали непевність і тимчасовість людського існування. Світ рослин і тварин і його тлумачення відображало досягнення середньовічних трактатів, тести «Бестіріїв», а легендарний «театральний коник» прийшов сюди із міських народних вистав і середньовічних містерій. I все це в поєднанні представляло космологічні виміри не лише Антніо Феррабоско а й усього тогочасного англійського суспільства.

Ця проблема багатовекторна й недостатньо досліджена на сьогоднішній день. Одним із пріоритетних іiі напрямів уважаємо вивчення символізму «доглобусівських» англійських театрів, зокрема легендарної шекспірівської «Завіси», та поширення цих традицій на європейські землі. 


\section{Список використаних джелел}

Адиссон Р. К. Существуєт ли английский театр? Из истории английского театра : сб. статей / под. ред. М. А. Соловникова. Екатерингург : У-Фактория, 2005. С. 11-34.

Всеволодский Г. П. История театрального образования в Европе и России : в 3 т. Т. 1. Санкт-Петербург, 1913.

Дживелегов А. С., Бояджиев Г. К. История западноевропейского театра от возникновения до 1789 года. Москва : Высш. шк.,1984. 489 с.

Саприкіна Д. «Завіса» Шекспіра відкрилася. Митці минулих епох очима їхніх сучасників (початок XVII - середина XIX ст.) : наук.-популярне вид. / автор-укладач І. Цебрій. Полтава : Формат+, 2019. С. 16-20.

Цебрій І. В. Розуміння «людини» і «людяності» в творчості митців-драматургів «постшекспірівської» епохи. Люди на та людяність у світовій гуманітарній традиції. Полтава : АСТРАЯ, 2019. С. 48-55.

\section{References}

Adisson, R. K. \& Solovnikova, M. A. (Ed.). (2005). Sushchestvu€t li angliiskii teatr? [Is there an English theater?]. In Iz istorii angliiskogo teatra [From the history of English theater] (pp. 11-34). Ekateringurg: U-Faktoriia [in Russian].

Dzhivelegov, A. S., \& Boiadzhiev, G. K. (1984). Istoriia zapadnoevropeiskogo teatra ot vozniknoveniia do 1789 goda [The history of the Western European theater from its inception to 1789]. Moskva: Vyssh. shk. [in Russian].

Saprykina, D. \& Tsebrii, I. (Comp.). (2019). "Zavisa" Shekspira vidkrylasia [Shakespeare's "veil" opened]. In Myttsi mynulykh epokh ochyma yikhnikh suchasnykiv (pochatok XVII - seredyna XIX st.) [Artists of past epochs in the eyes of their contemporaries (beginning of the 17th - the middle of the nineteenth century)] (pp. 16-20). Poltava: Format+ [in Ukrainian].

Tsebrii, I. V. (2019). Rozuminnia "liudyny" i "liudianosti" v tvorchosti myttsivdramaturhiv "postshekspirivskoi" epokhy [Understanding of "man" and "humanity" in the works of playwrights "post-Shakespearean" era]. In Liudy na ta liudianist $u$ svitovii humanitarnii tradytsii [People on that humanity in the world of humanitarian tradition] (pp. 48-55). Poltava: ASTRAIa [in Ukrainian].

Vsevolodskii, G. P. (1913). Istoriia teatralnogo obrazovaniia v Evrope i Rossii [History of theatrical education is in Europe and Russia]. (Vol. 1). SanktPeterburg [in Russian].

\section{Iryna Tsebriy}

\section{THE PERCEPTIONS OF HARMONY OF HUMAN LIFE AND COSMOLOGICAL DIMENSIONS IN THE WORKS OF ANTONIO FERRABOSCO}

The article deals with the harmony of human life and cosmological dimensions in Antonio Ferrabosco's work, which was the English art phenomenon of the turn of the seventeenth and eighteenth centuries. Analyzing the leading researchers 
works of the English theater and the original texts of musical performances by Antonio Ferrabosko, the author reveals the symbolism of the English theater in the transitional stage from the late Middle Ages to the early Northern Renaissance. At the same time, the versatility of this symbolism is denied by the opinion of the nineteenth-century researchers that only music and poetry sounded in the "Globe" theater, and theatrical performance was completely absent. It is stated that the harmony of music had a purpose to become the organizational basis of the entire play, contain its plastic images, and to show cosmological dimensions of englanders on the turn of ages.

The idea of the harmony of human life and cosmological dimensions in the works of Antonio Ferrabosco were indeed an English art phenomenon of the turn of the seventeenth to eighteenth centuries. Each piece of play or theatrical decoration had its symbolic meaning. The wedge-shaped "Globe" scene depicted a lone ship traveling among the unpredictable elements of the planet (the universe). The theatrical change of light and daylight stressed the uncertainty and temporality of human existence. The world of plants and animals and its interpretation reflected the achievements of medieval treatises, the tests of "Bestiriev", and the legendary "theater horse" came here from the urban folk performances and medieval mysteries. And all this, in combination, represented cosmological dimensions not only of Anthony Ferrabosco but also of all that time of English society.

This problem is multivector and insufficiently investigated to date. One of its priority areas is the study of the symbolism of the "before-Globe" British theaters, in particular the legendary Shakespearean "Curtain", and the spread of these traditions to European lands.

Keywords: cosmological dimensions, harmony, symbolism, theatrical performance, music, "theater of masks", Northern Renaissance. 